\title{
Kondisi Kualitas Air Sungai Surabaya Studi Kasus: Peningkatan Kualitas Air Baku PDAM Surabaya
}

\author{
Water Quality Condition of Surabaya River \\ Case Study: Improved Raw Water of PDAM Surabaya
}

\author{
SATMOKO YUDO, NUSA IDAMAN SAID
}

\author{
Pusat Teknologi Lingkungan, Badan Pengkajian dan Penerapan Teknologi \\ Gedung Geostech 820 Lt.2, Kawasan Puspiptek, Tangerang Selatan, 15314 \\ Email : satmoko.yudo@bppt.go.id
}

\begin{abstract}
The disposal of domestic and industrial waste to Surabaya river continues to increase, resulting in worse physical condition and severe pollution. The existence of Surabaya river is very important for the sustainability of the economy and the survival of society, industry, and commerce around the riverbank. In addition, Surabaya River becomes the raw water source of PDAM Surabaya and more than 3 million consumers of Surabaya PDAM depend on the water quality condition of Surabaya River. The purpose of this activity is to know the current condition of Surabaya River's water quality and to determine the technology that can improve the water quality of PDAM. The conclusion that can be drawn from the water quality condition of Surabaya River is the high concentration of organic matter pollutants. Moreover, it is increasing in the dry season. With the increasingly poor quality of raw water coming from Surabaya river, consequently, the cost of processing will become more expensive. Therefore, conventional processing is not able to eliminate the pollutant compounds. One alternative technology to improve the quality of raw water is to apply a pretreatment process with the process biological by using biofilter technology.
\end{abstract}

Keywords: water quality in Surabaya River, Surabaya Municipal Waterworks (PDAM), Biofilter technology

\begin{abstract}
ABSTRAK
Pembuangan limbah domestik dan industri di sepanjang Kali Surabaya terus meningkat, mengakibatkan kondisi fisik sungai semakin memburuk dan mengalami pencemaran semakin berat. Keberadaan kali Surabaya sangat penting bagi keberlangsungan perekonomian dan kelangsungan hidup bagi masyarakat, industri, dan niaga di sekitar bantaran kali. Selain itu Kali Surabaya menjadi sumber air baku PDAM Surabaya dan lebih dari tiga juta konsumen PDAM Surabaya bergantung pada kondisi kualitas air Kali Surabaya. Tujuan kegiatan ini adalah untuk mengetahui kondisi kualitas air Kali Surabaya dan menentukan teknologi yang dapat meningkatkan kualitas air baku PDAM. Kesimpulan yang dapat diambil dari kondisi kualitas air Kali Surabaya adalah tingginya konsentrasi polutan zat organik yang semakin meningkat pada musim kemarau. Dengan semakin buruknya kualitas air baku yang berasal dari Kali Surabaya, akibatnya biaya pengolahan akan menjadi semakin mahal dan pengolahan secara konvesional tidak mampu menghilangkan senyawa polutan tersebut Salah satu teknologi alternatif untuk meningkatkan kualitas air baku PDAM adalah dengan menerapkan proses pengolahan awal (pretreatment) dengan proses biologis menggunakan teknologi biofilter.
\end{abstract}

Kata kunci: kualitas air Kali Surabaya, PDAM Surabaya, Teknologi Biofilter

\section{PENDAHULUAN}

\subsection{Latar Belakang}

Air baku adalah air yang dapat berasal dari sumber air permukaan, cekungan air tanah dan/atau air hujan yang memenuhi baku mutu tertentu sebagai air baku untuk air minum ${ }^{(1)}$. Kali Surabaya merupakan anak sungai Kali Brantas yang berawal dari pintu air Dam Mlirip sampai dengan pintu air Jagir, yang merupakan sungai lintas kabupaten/kota. Kali Surabaya saat ini berfungsi sebagai sumber air baku untuk kebutuhan pemakaian air bersih di wilayah Surabaya dan sekitarnya, termasuk bagi industri dan PDAM. Seiring pesatnya pertumbuhan pemukiman dan perkembangan sektor industri, mengakibatkan semakin tingginya tingkat pencemaran di Sungai Surabaya. Hal tersebut berpengaruh pada menurunnya kualitas air akibat polutan khususnya polutan organik dari limbah domestik maupun limbah industri. Sehingga Kali Surabaya memiliki kualitas air baku yang kurang memenuhi ketentuan baku mutu yang dipersyaratkan oleh Pemerintah 
Provinsi Jawa Timur. Berdasarkan pemantauan Badan Lingkungan Hidup Kota Surabaya tahun 2013, menunjukkan $69,45 \%$ berstatus cemar ringan, 22,22\% cemar sedang dan $8,33 \%$ cemar berat dengan parameter BOD dan TSS

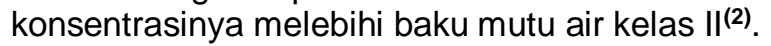

Dengan kondisi seperti ini maka biaya pengolahan air menjadi bertambah besar dan resiko penurunan kualitas air olahan menjadi lebih besar. Hampir semua kasus pencemaran air mempengaruhi tidak hanya individu dan masyarakt tetapi juga biota liar alami. Di Indonesia dan juga di negara berkembang, hampir separuh penduduk menderita masalah kesehatan yang terkait dengan konsumsi air yang terkontaminasi mikro-organisme ${ }^{(3)}$. Proses klorinasi adalah tahap yang paling vital dalam pengolahan air minum, tetapi senyawa terklorinasi tidak boleh dikonsumsi ${ }^{(4)}$. Prosedur untuk desinfeksi air menggunakan klorin digunakan di seluruh dunia untuk mengurangi risiko kesehatan yang terkait dengan pertumbuhan mikroorganisme patogen dalam air minum. Meskipun proses klorinasi ini sangat penting, beberapa produk hasil samping proses desinfeksi yang tidak diinginkan umumnya teridentifikasi dalam air minum yang diolah dengan klorinasi misalnya trihalometan dan klorofenol(5,6).

Senyawa hasil samping proses disinfeksi dapat terjadi disebabkan karena kualitas air baku yang diolah mengandung polutan organik yang cukup tinggi. Dengan banyaknya senyawa hasil samping proses klorinasi yang umumnya berupa senyawa hidrokarbon terklorinasi misalnya senyawa trihalometan (THMs), khlorophenol, khlorobenzene dan lainnya yang mana senyawasenyawa tersebut mempunyai sifat karsinogen dan kadang-kadang mempunyai sifat mutagenik, maka keberadaannya di dalam air minum yang disuplai ke masyarakat perlu dikontrol dan diawasi(7).

Untuk mencegah atau memperkecil resiko akibat senyawa mikro polutan di dalam air minum dapat dilakukan dengan beberapa cara antara lain memperbaiki kualitas air baku yang digunakan untuk air minum dan juga dengan memilih teknologi pengolahan air yang sesuai dengan kualitas air olahan yang diharapkan.

\subsection{Tujuan Penelitian}

Tujuan dari penelitian ini adalah untuk mengetahui kondisi pencemaran kualitas air kali Surabaya.

\section{BAHAN DAN METODE}

\subsection{Bahan}

Bahan yang digunakan dalam kegiatan ini adalah data sekunder dari tahun 2010 sampai
2013 tentang data pemeriksaan rutin kualitas air di:
Dam Gunungsari,
Pintu Air Jagir / Ngagel,
Pompa Gunungsari I (Inlet-outlet),
Pompa Gunungsari II (hulu-hilir),
Intake PDAM Ngagel

\subsection{Metode}

Metode yang digunakan dalam kajian ini antara lain sebagai berikut:

a) Pengumpulan Data

Dalam studi ini data yang diperlukan adalah data sekunder. Data sekunder diperoleh dengan pengumpulan data-data yang diperlukan seperti data kualitas air, dan lainnya.

b) Analisis Data

Dalam menganalisis data digunakan metode serta acuan standar yang telah ditetapkan dalam Standar Nasional Indonesia (SNI), Keputusan Menteri dan aturan pendukung lainnya. Analisis data meliputi data kualitas air, analisis teknologi biofilter, rekomendasi teknis penerapan biofilter dan perhitungan biaya yang dibutuhkan.

\section{HASIL DAN PEMBAHASAN}

\subsection{Kondisi Umum Kali Surabaya}

Kali Surabaya merupakan bagian dari sistem aliran Sungai Brantas Hilir. Peruntukkan utama pada bagian hulu adalah sebagai sumber air irigasi untuk sekitar 800.000 hektar areal pertanian. Peruntukkan yang lain pada bagian hulu dipergunakan sebagai air baku untuk keperluan domestik penduduk kota Surabaya dan sekitarnya. Di beberapa lokasi, air Kali Surabaya dipergunakan untuk pembudidayaan ikan kurang lebih seluas 4.000 hektar areal perikanan.

Selain itu, Kali Surabaya dipergunakan juga untuk tempat buangan air limbah industri dan sekaligus sebagai air proses bagi industri yang berlokasi di wilayah DAS Kali Surabaya. Kali Surabaya khususnya di bagian hilir juga berfungsi sebagai drainase bagi pemukiman yang ada di sekitar sungai, sehingga dengan semakin padatnya pemukiman yang ada di daerah aliran Kali Surabaya menyebabkan tingkat pencemaran sungai oleh air limbah domestik menjadi bertambah besar ${ }^{(8)}$.

Perum Jasa Tirta I telah melakukan pemantauan rutin terhadap kualitas air Kali Surabaya. Beberapa titik lokasi yang dipantau yaitu Dam Gunung sari, Muara Kali Kedurus, Pompa Gunung Sari I, Pompa Gunung Sari II, Pintu Air Jagir dan Intake PDAM. Peta lokasi sampling dapat dilihat pada Gambar 1. 


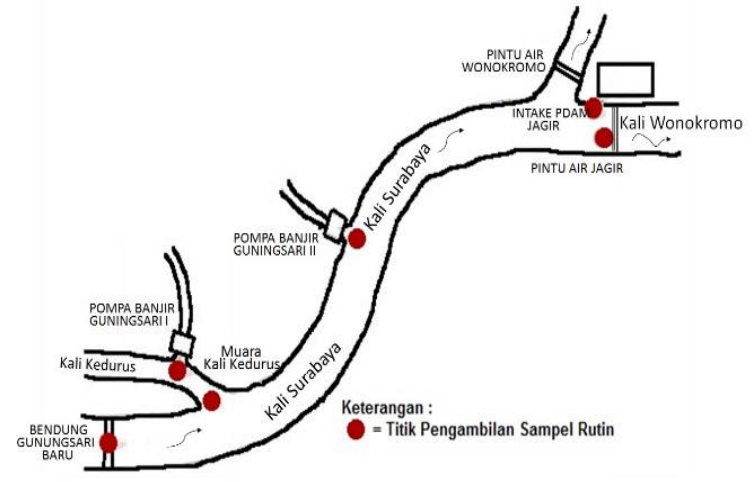

Gambar 1. Lokasi Titik Sampling di Dam Gunung sari, Muara Kali Kedurus, Pompa Gunung Sari I, Pompa Gunung Sari II, Pintu Air Jagir dan Intake PDAM(8)

\subsection{Hasil Pemantauan Kualitas Air Kali Surabaya di Lokasi Dam Gunung Sari}

Dari hasil pemantauan kualitas Kali Surabaya mulai dari daerah Gunung Sari sampai Wonokromo (Dam Jagir dan Intake PDAM IPA Ngagel) dari Tahun 2010 sampai Tahun 2013 adalah sebagai berikut:

\section{a. Parameter BOD}

Dari hasil pemantauan terhadap parameter BOD air Kali Surabaya di lokasi Dam Gunung Sari dari tahun 2010 sampai tahun 2013, nilai BOD berkisar antara 2,56 dan 11,94 mg/l atau rata-rata 4,186 mg/l (Gambar 2). Peningkatan konsentrasi BOD tidak menunjukkan kecenderungan yang jelas dan dapat terjadi pada saat musim kemarau maupun pada musim hujan. Kecenderungan peningkatan konsentrasi BOD pada musim hujan bisa disebabkan karena peggelontoran air limbah domestik dari pemukiman atau kemungkinan ada pembuangan air limbah industri. Dari hasil laporan tim patroli air gabungan dari Kepolisian, Dinas Lingkungan Hidup, Perum Jasa Tirta I, Satpol PP Provinsi Jatim dan Dinas Kominfo mengatakan bahwa beberapa industri membuang limbahnya dengan sengaja ke kali Surabaya ${ }^{(9)}$.

Jika dibandingkan dengan Standar Mutu Air Kelas I sesuai dengan PP Nomor 82 Tahun 2001(10), hal ini menunjukkan bahwa air Kali Surabaya telah tercemar oleh polutan organik cukup tinggi.

Standar mutu air kelas 1 untuk penggunaan air baku air minum konsentrasi BOD maksimum adalah $2 \mathrm{mg} / \mathrm{l}$, sedangkan untuk mutu air kelas 2 untuk penggunaan prasarana/sarana rekreasi air, pembudidayaan ikan air tawar, peternakan, air untuk mengairi pertanaman, konsentrasi BOD maksimum $3 \mathrm{mg} / \mathrm{I}^{(10)}$.

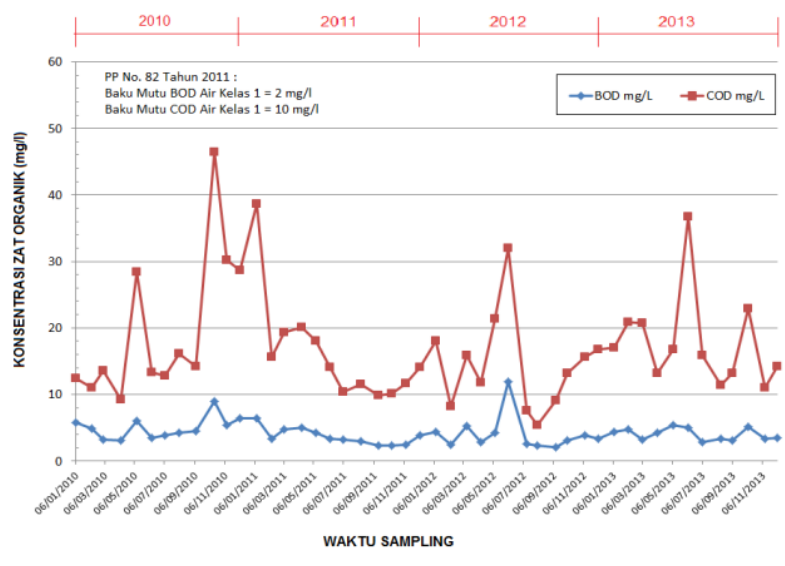

Gambar 2. Konsentrasi BOD dan COD di Kali Surabaya di Dam Gunung Sari

\section{b. Parameter COD}

Dari hasil pemantau parameter COD air Kali Surabaya di lokasi Dam Gunung Sari dari tahun 2010 sampai tahun 2013, nilai COD berkisar antara 8,19 1-46,499 $\mathrm{mg} / \mathrm{l}$ atau rata-rata 17,054 $\mathrm{mg} / \mathrm{l}$ (Gambar 2).

Peningkatan konsentrasi COD hampir sama dengan $\mathrm{BOD}$, tidak menunjukkan kecenderungan yang jelas dan dapat terjadi pada saat musim kemarau maupun pada musim hujan. Kecenderungan peningkatan konsentrasi COD pada musim hujan dapat disebabkan karena peggelontoran pembuangan air limbah air limbah industri.

Jika dibandingkan dengan standar mutu air kelas 1 sesuai dengan PP Nomor 82 Tahun 2001, maka mutu air kelas 1 untuk penggunaan air baku air minum konsentrasi COD maksimum adalah $10 \mathrm{mg} / \mathrm{l}$, sedangkan untuk mutu air kelas 2 untuk penggunaan prasarana/sarana rekreasi air, pembudidayaan ikan air tawar, peternakan, air untuk mengairi pertanaman, konsentrasi BOD maksimum $25 \mathrm{mg} / \mathrm{l}$.

Hal yang perlu diwaspadai adalah pada saat tertentu konsentrasi COD dapat mencapai diatas $40 \mathrm{mg} / \mathrm{l}$. Hal ini akan masalah yang serius jika digunakan untuk air baku air minum.

\section{c. Parameter TSS}

Dari hasil pemantau parameter TSS air Kali Surabaya di lokasi Dam Gunung Sari dari tahun 2010 sampai tahun 2013, nilai TSS berkisar antara 14,7 dan $1.000 \mathrm{mg} / \mathrm{l}$ atau rata-rata 162,90 $\mathrm{mg} / \mathrm{l}$ (Gambar 3). Jika dibandingkan dengan standar mutu air kelas I untuk penggunaan air baku air minum, maupun untuk mutu air kelas II untuk penggunaan prasarana/sarana rekreasi air, pembudidayaan ikan air tawar, peternakan, air untuk mengairi pertanaman sesuai dengan PP Nomor 82 Tahun 2001, konsentrasi TSS maksimum $50 \mathrm{mg} / \mathrm{l}$. 


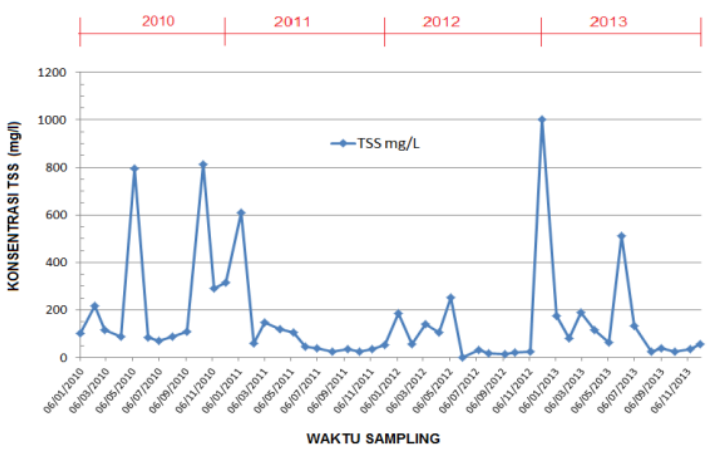

Gambar 3. Konsentrasi TSS Air Kali Surabaya di Dam Gunung Sari

Dari hasil plot hasil pemantauan BOD, COD dan TSS, dapat dilihat bahwa kecenderungan kenaikan BOD dan COD seiring dengan kenaikan konsentrasi TSS (Gambar 4). Kenaikan TSS sangat dipengaruhi oleh debit air terutama pada saat hujan. Jika debit air tinggi maka konsentrasi TSS akan meningkat. Dengan demikian dapat disimpulkan bahwa kenaikan konsentrasi BOD atau COD terjadi pada saat hujan atau pada saat debit air meningkat. Hal ini kemungkinan disebabkan karena banyaknya air limbah domestik dari pemukiman yang masuk ke dalam sungai atau kemungkinan ada pembuangan air limbah industri yang dilakukan pada saat hujan.

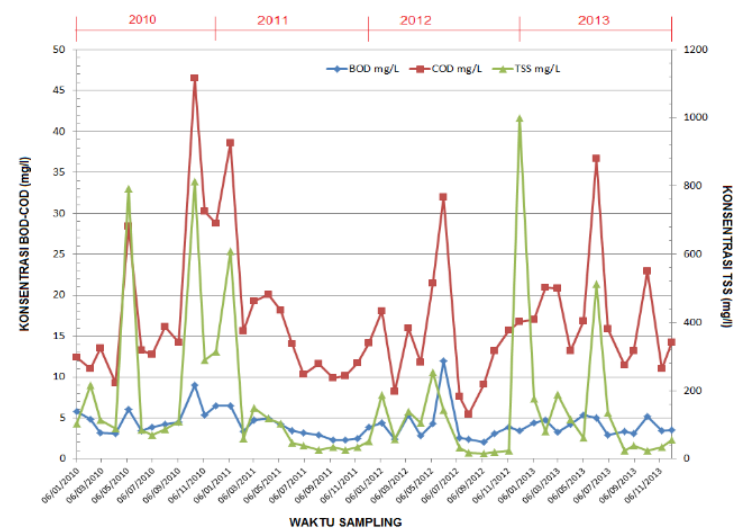

Gambar 4. Konsentrasi BOD, COD dan TSS Air Kali Surabaya di Dam Gunung Sari

\section{d. Parameter DO}

Konsentrasi parameter DO air Kali Surabaya di lokasi Dam Gunung Sari dari tahun 2010 sampai tahun 2013, nilai DO berkisar antara 2,1$5,9 \mathrm{mg} / \mathrm{l}$ atau rata-rata $3,5 \mathrm{mg} / \mathrm{l}$ (Gambar 5). Jika dibandingkan dengan Standar Mutu Air Kelas I sesuai dengan PP Nomor 82 Tahun 2001, maka baku mutu air Kelas I untuk penggunaan air baku air minum konsentrasi DO minimum adalah 6 $\mathrm{mg} / \mathrm{l}$, sedangkan untuk mutu air kelas II untuk penggunaan prasarana/sarana rekreasi air, pembudidayaan ikan air tawar, peternakan, air untuk mengairi pertanaman, konsentrasi DO minimum $4 \mathrm{mg} / \mathrm{l}$.

Konsentrasi DO yang rendah dapat mengakibatkan kematian masal ikan biota lain yang ada di dalam sungai. Selain itu, konsentrasi DO yang sangat rendah dapat menyebabkan kondisi lingkungan sungai menjadi anaerob sehingga dapat mengakibatkan timbulnya gas hidrogen sulfida $\left(\mathrm{H}_{2} \mathrm{~S}\right)$ penyebab bau.

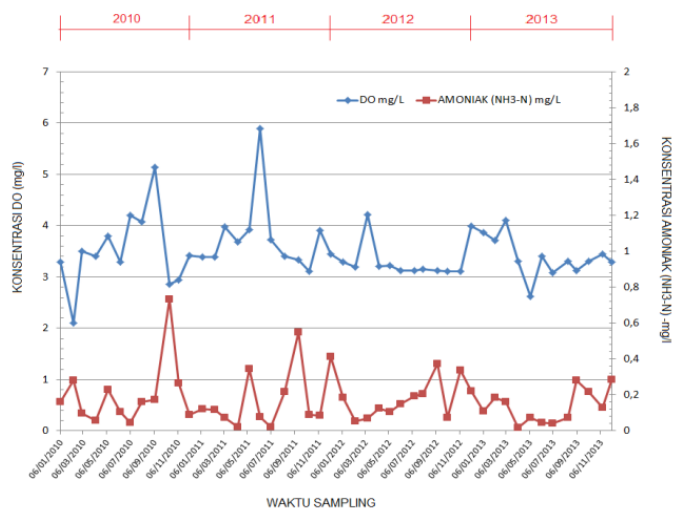

Gambar 5. Konsentrasi DO dan Amoniak Air Kali Surabaya di Dam Gunung Sari

\section{e. Parameter Amoniak $\left(\mathrm{NH}_{3}-\mathrm{N}\right)$}

Senyawa amoniak merupakan racun bagi biota air. Selain itu apabila digunakan untuk air baku air minum dapat bereaksi dengan senyawa khlor sehingga kebutuhan khlor menjadi lebih besar. Semakin besar senyawa khlor yang digunakan untuk proses disinfeksi maka khlor dapat bereaksi dengan senyawa polutan organik yang ada di dalam air membentuk senyawa trihalomethan yang bersifat karsinogen. Menurut Wikipedia bahwa zat-zat karsinogen dapat menyebabkan penyakit kanker dengan mengubah asam deoksiribonukleat (DNA) dalam sel-sel tubuh, dan hal ini mengganggu prosesproses biologis.

Dari hasil pemantauan parameter Amoniak air Kali Surabaya di lokasi Dam Gunung Sari dari tahun 2010 sampai tahun 2013, konsentrasi Amoniak berkisar antara 0,019 dan $0,732 \mathrm{mg} / \mathrm{l}$ atau rata-rata 0,172 $\mathrm{mg} / \mathrm{l}$ (Gambar 5). Jika dibandingkan dengan standar mutu air kelas I sesuai dengan PP Nomor 82 Tahun 2001, maka untuk parameter amoniak masih memenuhi mutu air kelas I (BM Amoniak $=0,5 \mathrm{mg} / \mathrm{l}$ ) untuk penggunaan air baku air minum.

\section{f. Parameter Fenol}

Dari hasil pemantauan kualitas air Kali Surabaya di lokasi Dam Gunung Sari, senyawa fenol sering muncul dengan konsentrasi berkisar antara 0 dan 0,039 $\mathrm{mg} / \mathrm{l}$, dan pada bulan Desember 2012 konsentrasi Fenol bahkan mencapai $5 \mathrm{mg} / \mathrm{l}$ (Gambar 6). Berdasarkan PP 
Nomor 82 Tahun 2001, untuk mutu air kelas I untuk penggunaan air baku air minum konsentrasi senyawa fenol maksimum adalah 1 $\mu \mathrm{g} / \mathrm{l}$ atau $0,001 \mathrm{mg} / \mathrm{l}$.

Senyawa Fenol $\left(\mathrm{C}_{6} \mathrm{H}_{5} \mathrm{OH}\right)$ merupakan senyawa dengan gugus hidroksil $(-\mathrm{OH})$ berikatan pada hidrokarbon aromatis yang dapat berupa padatan kristal putih dengan bau yang khas. Senyawa fenol terdapat dalam limbah industri obat-obatan, industri plastik, industri batu bara, industri kimia, industri bahan peledak, industri tekstil dan kilang minyak.

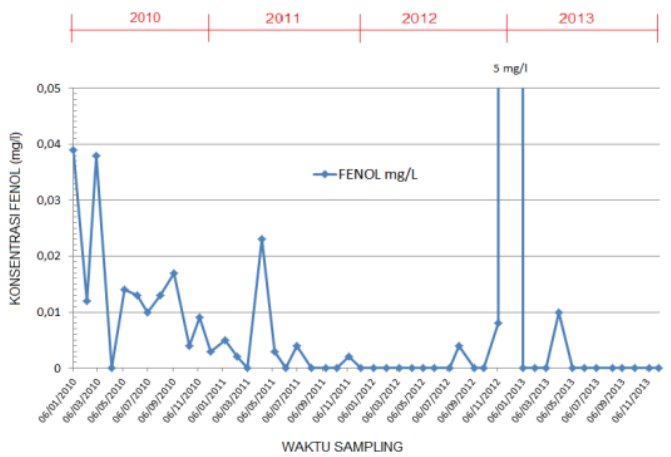

Gambar 6. Konsentrasi Fenol Air Kali Surabaya di Dam Gunung Sari

Senyawa fenol jarang dijumpai dalam keadaan murni, pada umumnya bergabung dengan senyawa-senyawa turunannya seperti pentaklorofenol (PCP), 2,4,6-triklorofenol (TCP), nitrofenol, dan juga dinitrofenol (DNP).

Senyawa fenol memiliki toksisitas yang tinggi terhadap biota aquatik di perairan dengan tingkat toksisitas yang berbeda-beda terhadap berbagai jenis biota aquatik. Toksisitas ini sangat dipengaruhi oleh faktor fisika dan kimia air itu sendiri. Pada keadaan temperatur yang tinggi dan kelarutan oksigen dalam air rendah, maka toksisitas terhadap biota aquatik akan bertambah tinggi. Jika $\mathrm{pH}$ air tinggi, maka laju degradasi senyawa ini akan menjadi rendah pula. Hal ini di karenakan pada $\mathrm{pH}$ rendah aktivitas mikroorganisme akan terhambat dan di samping itu oksigen tidak dapat larut pada $\mathrm{pH}$ air yang rendah, sehingga akan mengurangi persediaan oksigen yang diperlukan mikroorganisme untuk menguraikan senyawa fenol dalam air ${ }^{(11)}$.

Kontaminasi fenol pada manusia dapat menyebabkan berbagai penyakit mulai dari iritasi, gangguan saraf, kerusakan hati dan ginjal hingga penyakit kronis yang bersifat karsinogenik (menyebabkan kanker) dan teratogenik (menyebabkan cacat kelahiran) $^{(12)}$.

\subsection{Hasil Pemantauan Kualitas Air di Pompa Gunung Sari I dan Pompa Gunung Sari II}

Untuk mengatasi permasalahan banjir di Kali Surabaya, dilakukan dengan pengaturan pintu air dan pengoperasian pompa banjir menuju Kali Surabaya. Pompa banjir di sepanjang Kali Surabaya difungsikan untuk memompa air dari collector drainage perkotaan agar dapat masuk ke Kali Surabaya sehingga banjir di perkotaan dapat terhindarkan. Beberapa Pompa banjir yang ada di sekitar Sungai Surabaya adalah Pompa Gunung Sari I dan Pompa Gunung Sari II. Dengan adanya pengoperasian pompa banjir di Kali Surabaya akan berdampak kepada kualitas air di Sungai Surabaya karena limbah domestik yang tertampung pada drainase perkotaan akan masuk Kali Surabaya melalui proses pemompaan tersebut.

\section{a. Stasiun Pompa Gunung Sari I}

Hasil pemantauan kualitas air menunjukkan bahwa konsentrasi BOD sebelum pompa Gunung Sari I berkisar antara 1,65 dan 25,1 mg/l atau rata-rata $11,77 \mathrm{mg} / \mathrm{l}$, sedangkan konsentrasi BOD sesudah Pompa Gunung Sari I berkisar antara 3,07 dan $17,69 \mathrm{mg} / \mathrm{l}$ atau rata-rata 8,59 $\mathrm{mg} / \mathrm{l}$ (Gambar 10).

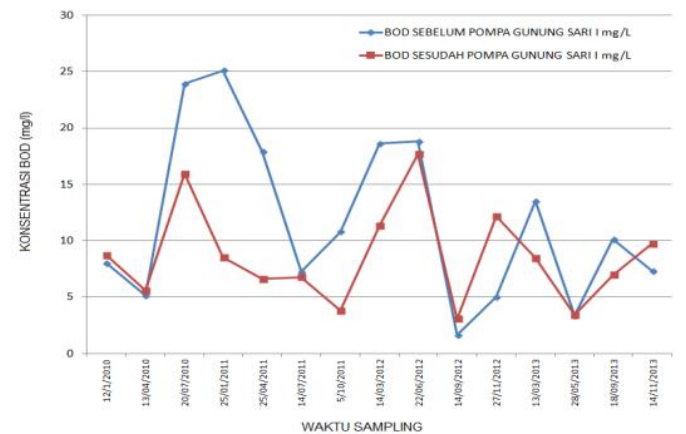

Gambar 10. Konsentrasi BOD Sebelum dan Sesudah Pompa Gunung Sari I

Untuk parameter TSS, konsentrasi Sebelum Pompa berkisar antara 4,0 dan $111,5 \mathrm{mg} / \mathrm{l}$ atau rata-rata $35,06 \mathrm{mg} / \mathrm{l}$, sedangkan konsentrasi TSS sesudah pompa berkisar antara 4 dan $110 \mathrm{mg} / \mathrm{l}$ atau rata-rata $32,43 \mathrm{mg} / \mathrm{l}$ (Gambar 11).

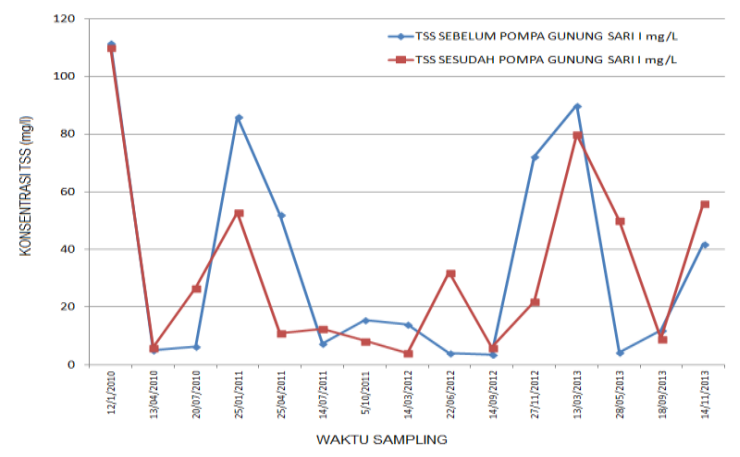

Gambar 11. Konsentrasi TSS Sebelum dan Sesudah Pompa Gunung Sari I 


\section{b. Stasiun Pompa Gunung Sari II}

Hasil pemantauan kualitas air menunjukkan bahwa konsentrasi BOD sebelum pompa Gunung Sari II berkisar antara 2,01 dan 19,67 $\mathrm{mg} / \mathrm{l}$ atau rata-rata $8,84 \mathrm{mg} / \mathrm{l}$, sedangkan konsentrasi BOD sesudah Pompa Gunung Sari II berkisar antara 3,03 dan $28,21 \mathrm{mg} / \mathrm{l}$ atau ratarata $9,98 \mathrm{mg} / \mathrm{l}$ (Gambar 12).

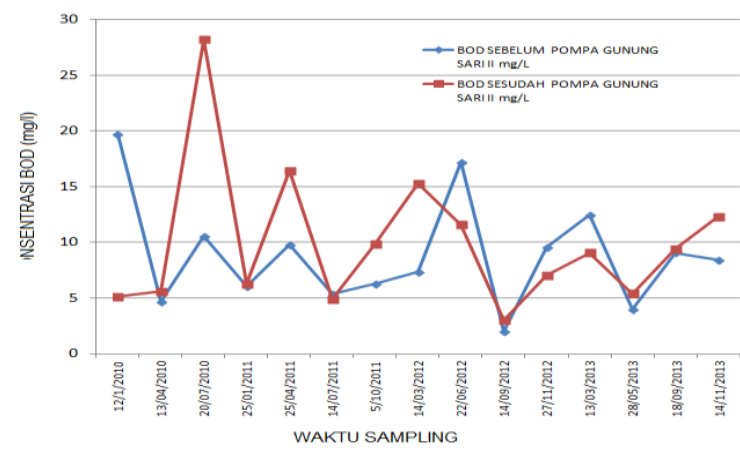

Gambar 12. Konsentrasi BOD Sebelum dan Sesudah Pompa Gunung Sari II

Untuk parameter TSS, konsentrasi Sebelum Pompa berkisar antara 3,0 dan $510 \mathrm{mg} / \mathrm{l}$ atau rata-rata $51,11 \mathrm{mg} / \mathrm{l}$, sedangkan konsentrasi TSS sesudah pompa berkisar antara 6,3 dan $510 \mathrm{mg} / \mathrm{l}$ atau rata-rata $71,35 \mathrm{mg} / \mathrm{l}$ (Gambar 13).

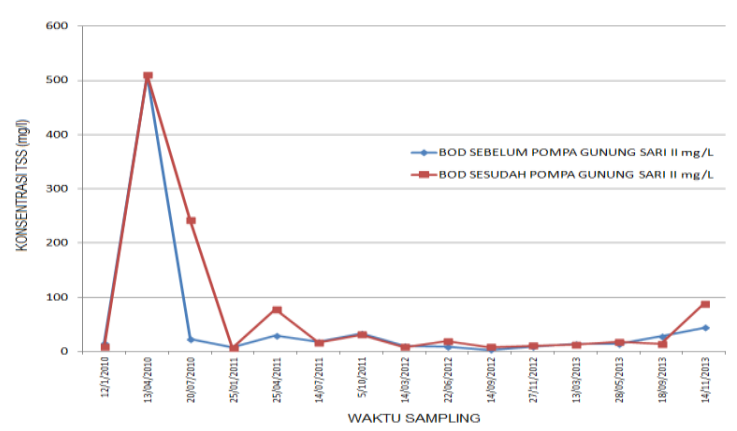

Gambar 13. Konsentrasi TSS Sebelum dan Sesudah Pompa Gunung Sari II

\subsection{Hasil Pemantauan Kualitas Air Kali Surabaya di Lokasi Intake PDAM Jagir}

Dari hasil pemantauan air Kali Surabaya di lokasi Intake PDAM Jagir dari tahun 2010-2013, konsentrasi BOD berkisar antara 2,24 dan 14,84 $\mathrm{mg} / \mathrm{l}$ atau rata-rata $5,715 \mathrm{mg} / \mathrm{l}$ (Gambar 14). Untuk konsentrasi COD berkisar antara 10,0 dan $53,87 \mathrm{mg} / \mathrm{l}$ atau rata-rata $22,86 \mathrm{mg} / \mathrm{l}$ (Gambar 14). Konsentrasi TSS berkisar antara 17,0 dan $209,0 \mathrm{mg} / \mathrm{l}$ atau rata-rata $59,59 \mathrm{mg} / \mathrm{l}$ (Gambar 15). Konsentrasi oksigen terlarut (DO) berkiasar antara 3,1 dan $4,33 \mathrm{mg} / \mathrm{l}$ atau rata-rata $3,27 \mathrm{mg} / \mathrm{l}$ (Gambar 15). pH air berkisar antara 6,1 dan 7,39 atau rata-rata 7,05 (Gambar 16).

Dari hasil pemantauan tersebut secara umum kondisi air Kali Surabaya di lokasi Intake
PDAM Jagir telah tercemar terutama oleh zat organik. Hal ini dapat dilihat bahwa konsentrasi BOD teringgi bisa mencapai $14,84 \mathrm{mg} / \mathrm{l}$ dan COD $53,87 \mathrm{mg} / \mathrm{l}$. Untuk $\mathrm{pH}$ air relatif masih normal yakni masih berkisar antara 6 dan 9 .

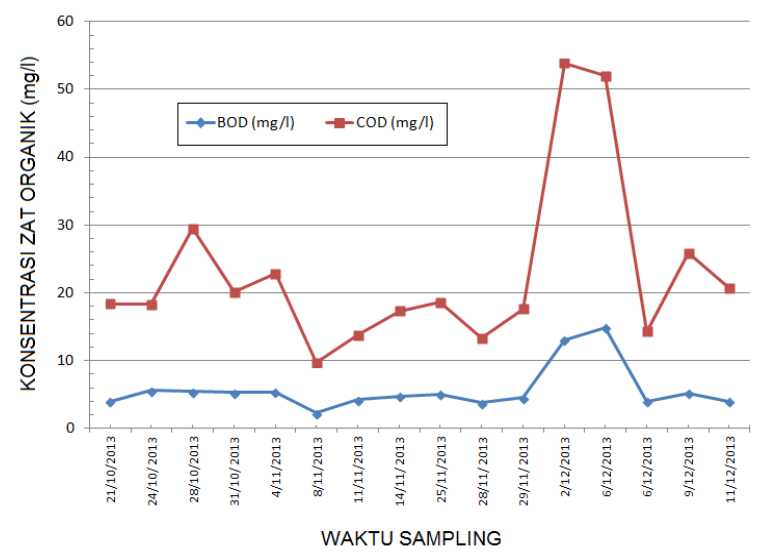

Gambar 14. Konsentrasi BOD Dan COD di Intake PDAM Jagir

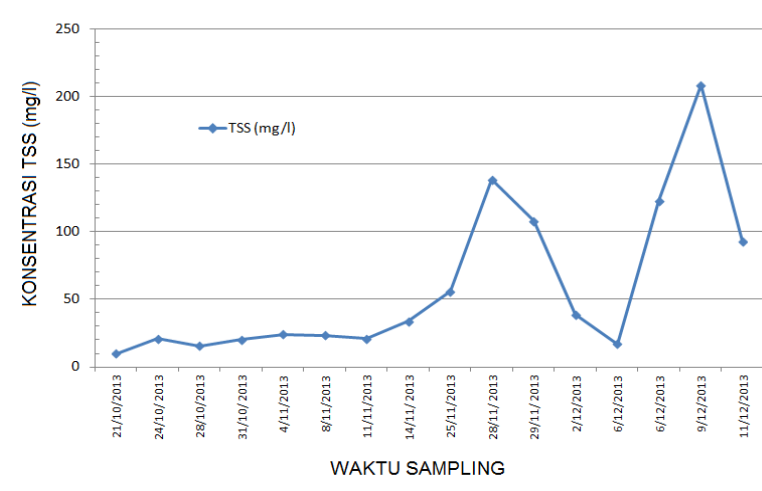

Gambar 15. Konsentrasi TSS Air Sungai di Intake PDAM Jagir

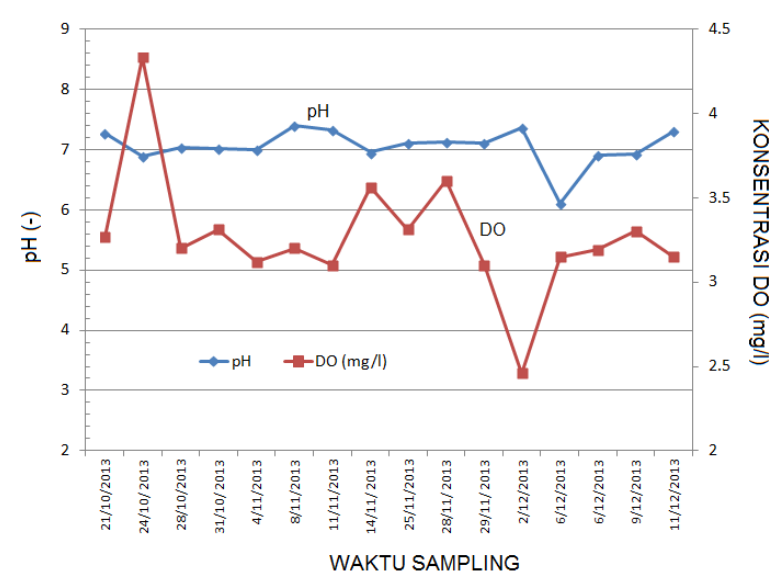

Gambar 16. Konsentrasi DO Dan pH di Intake PDAM Jagir

\subsection{Proses Pengolahan Air Minum di PDAM Surabaya}

Proses pengolahan air minum di PDAM Surabaya masih menggunakan proses 
konvensional yaitu proses pengolahan air minun dengan pengendapan kimia. Air baku yang digunakan adalah air sungai yang berasal dari Kali Surabaya. Proses pengolahannya secara umum seperti pada Gambar 17.

Air baku dialirkan ke bangunan intake yang dilengkapi dengan saringan kasar untuk menyaring sampah agar tidak masuk ke instalasi pengolahan. Selanjutnya air dialirkan ke bak prasedimentasi melalui kanal atau saluran terbuka. Dari bak pra-sedimentasi air dialirkan ke bak/kanal pencampur sambil diinjeksi dengan karbon aktif bubuk, larutan cupri sulfat dan klorin untuk proses preklorinasi. Pembubuhan karbon aktif diakukan untuk menurunkan konsentrasi senyawa polutan organik, polutan mikro atau bau terutama pada musim kemarau. Pembubuhan cupri sulfat dilakukan untuk mencegah tumbuhnya lumut, sedangkan preklorinasi dilakukan untuk menurunkan zat besi atau mangan yang ada di dalam air baku atau untuk membunuh kuman.

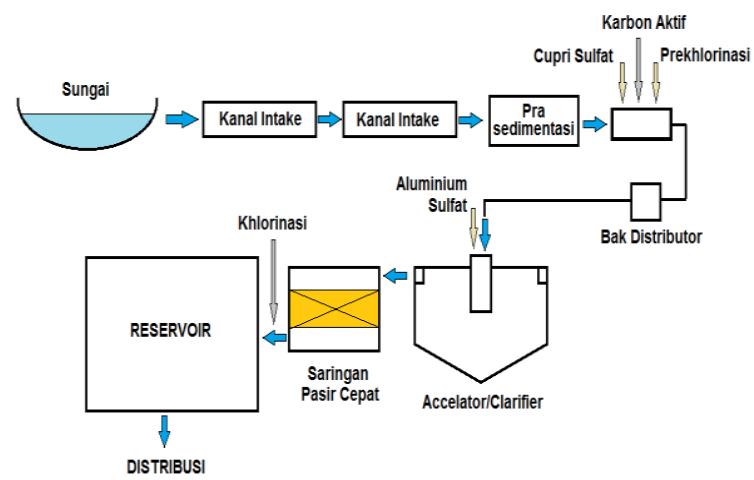

Gambar 17. Diagram Proses Pengolahan Air Minum yang Digunakan di PADM Surabaya ${ }^{(13)}$.

Selanjutnya, air di alirkan ke bak distributor, kemudian masuk ke accelerator atau Clarifier sambil dibubuhkan larutan bahan koagulan (Aluminum sulfat, Poly Alumunium Chloride/PAC) untuk menggumpalkan dan mengendapkan kotoran yang ada di dalam air. Di dalam tangki Accelator tersebut kotoran akan digumpalkan dan diendapkan, selanjutnya kotoran yang sudah mengendap dibuang, dan air limpasan dari tangki accelator yang sudah jernih masuk ke unit saringan pasir cepat (rapid sand filter) yang bekerja secara gravitasi. Saringan pasir cepat tersebut berfungsi untuk menyaring gumpalan kotoran (flok) halus yang belum terendapkan di tangki clarifier. Air yang sudah melalui saringan pasir adalah air olahan yang sudah bersih, dan selanjutnya dialirkan ke bak penampung (reservoir) sambil diinjeksi dengan khlorin untuk membunuh kuman.

Saat ini PDAM Surabaya mempunyai kapasitas pengolahan total sekitar 10.500 liter per detik ${ }^{(13)}$ yang terdiri dari beberapa instalasi yaitu IPA Karang Pilang I, IPA Karang Pilang II, IPA Karang Pilang III, IPA Ngagel I, IPA Ngagel II dan IPA Ngagel III seperti terlihat pada Tabel 1.

Dengan semakin buruknya kualitas air baku yang berasal dari Kali Surabaya, maka dengan proses pengolahan secara konvensional, maka penggunaan bahan kimia juga semakin besar, akibatnya biaya pengolahan akan menjadi semakin mahal.

Selain itu jika konsentrasi senyawa polutan yang ada di dalam air baku sangat tinggi, maka pengolahan secara konvensional dengan pengendapan kimia tidak akan mampu menghilangkan senyawa polutan tersebut.

Tabel 1. Debit Pemakaian Air PDAM Surya Sembada dari Kali Surabaya

\begin{tabular}{|c|c|c|c|c|}
\hline \multirow{2}{*}{ No } & \multirow{2}{*}{$\begin{array}{c}\text { Nama pemanfaat } \\
\text { air }\end{array}$} & \multirow{2}{*}{$\begin{array}{l}\text { Wilayah } \\
\text { adminis- } \\
\text { trasi }\end{array}$} & \multicolumn{2}{|c|}{$\begin{array}{c}\text { Volume } \\
\text { pemakaian }\end{array}$} \\
\hline & & & L/det & $\mathrm{M}^{3} /$ hari \\
\hline 1 & $\begin{array}{l}\text { PDAM Kota } \\
\text { Surabaya (IPA } \\
\text { Karangpilang I) }\end{array}$ & $\begin{array}{c}\text { Kota } \\
\text { Surabaya }\end{array}$ & 1.450 & 125.280 \\
\hline 2 & $\begin{array}{l}\text { PDAM Kota } \\
\text { Surabaya (IPA } \\
\text { Karangpilang II) }\end{array}$ & $\begin{array}{c}\text { Kota } \\
\text { Surabaya }\end{array}$ & 2.750 & 236.500 \\
\hline 3 & $\begin{array}{l}\text { PDAM Kota } \\
\text { Surabaya (IPA } \\
\text { Karangpilang III) }\end{array}$ & $\begin{array}{c}\text { Kota } \\
\text { Surabaya }\end{array}$ & 2.000 & 172.000 \\
\hline 4 & $\begin{array}{l}\text { PDAM Kota } \\
\text { Surabaya (IPA } \\
\text { Ngagel I \& II) }\end{array}$ & $\begin{array}{c}\text { Kota } \\
\text { Surabaya }\end{array}$ & 2.800 & 241.920 \\
\hline 5 & $\begin{array}{l}\text { PDAM Kota } \\
\text { Surabaya (IPA } \\
\text { Ngagel III) }\end{array}$ & $\begin{array}{c}\text { Kota } \\
\text { Surabaya }\end{array}$ & 1.750 & 151.200 \\
\hline & & TOTAL & 10.750 & 926.900 \\
\hline
\end{tabular}

Pembubuhan bahan kimia yang berlebihan terutama khlorin akan dapat menyebabkan reaksi samping antara khlorin dengan senyawa polutan membentuk senyawa organo-khlorin yang bersifat karsinogen ${ }^{(12)}$.

Salah satu cara untuk menanggulangi masalah tersebut adalah dengan menggunakan proses biologis dengan sistem biofilter tercelup menggunakan media plastik sarang tawon. Sistem biofilter adalah proses pengolahan air dengan cara mengalirkan air baku ke dalam bak atau reaktor yang diisi dengan media dari bahan plastik tipe sarang tawon dengan waktu kontak tertentu sambil dihembus atau diaerasi dengan udara. Dengan mengalirkan air baku ke dalam reaktor biofilter tersebut, maka akan terbentuk lapisan biofilm atau lapisan mikroorganisme yang melekat pada permukaan media. Mikroorganisme inilah yang akan menguraikan polutan yang ada di dalam air. 
Dengan proses biofiltrasi konsentrasi polutan organik, amoniak, detergen, padatan tersuspensi, zat besi, mangan akan dapat diturunkan sehingga konsumsi bahan kimia khususnya koagulan dan khlor untuk pengolahan air minum menjadi berkurang. Dengan demikian biaya produksi pengolahan air juga akan menjadi berkurang. Dengan semakin rendahnya konsentrasi amoniak di dalam air baku, maka penggunaan khor juga akan semakin sedikit, sehingga kemungkinan terjadinya senyawa hasil samping klorinasi misalnya trihalometan juga semakin kecil.

\subsection{Teknologi Biofilter Untuk Peningkatan Kualitas Air Baku PDAM Kali Surabaya}

Penelitian tentang peningkatan kualitas air baku air minum di Indonesia telah dilakukan oleh beberapa peneliti. Penelitian tentang penghilangan senyawa organik di dalam air baku dengan menggunakan proses biofilter dengan media plastik tipe sarang tawon telah dilakukan oleh Said dan Hidayati( ${ }^{(14)}$ dan dari hasil penelitian tersebut dapat dilihat bahwa dengan kondisi waktu tinggal hidrolis 1 jam efisiensi penghilangan zat organik 30,92\% untuk waktu tinggal 2 jam efisiensi sebesar $45,70 \%$ sedangkan pada waktu tinggal 3 jam sebesar $53,89 \%$ dan pada waktu tinggal 4 jam sebesar $64,27 \%$. Dari hasil penelitian Said dan Hidayati tersebut didapatkan hasil hubungan antara beban organik dan efisiensi penghilangan zat orgaik yakni semakin besar beban organik di dalam reaktor biofilter maka efisiensi penyisihan menjadi berkurang seperti terlihat pada Gambar 18.

Said dan Tresnawaty ${ }^{(15)}$ telah melakukan penelitian dengan mengoperasikan secara kontinyu satu reaktor biofilter tercelup menggunakan media plastik tipe sarang tawon dengan, ukuran $210 \mathrm{~cm} \times 30 \mathrm{~cm} \times 59 \mathrm{~cm}$, volume total 371,7 liter. Efisiensi penurunan amoniak berdasarkan variasi waktu tinggal hidrolis 1-3 jam berkisar antara $48,74 \%$ dan $73.59 \%$. Pada pengolahan dengan pengkondisian waktu tinggal hidrolis 1 jam efisiensi penurunan sebesar $48,4 \%$, untuk waktu tinggal 2 jam menunjukkan efisiensi sebesar $67,8 \%$, untuk waktu tinggal 3 jam efisiensi sebesar 73,59\%.

Said dan Nugroho ${ }^{(16)}$ telah melakukan penelitian untuk meningkatkan kualitas air baku PAM milik PT. Palyja Taman Kota dengan menggunakan proses biofiltrasi serta mengkaji kinerja reaktor biofilter dengan media plastik tipe sarang tawon terhadap penurunan konsentrasi zat organik, amoniak, deterjen (MBAS), besi, mangan serta padatan tersuspensi. Dari hasil penelitan tersebut disimpulkan bahwa efisisensi penghilangan polutan di dalam proses biofiltrasi sangat dipengaruhi oleh waktu tinggal di dalam reaktor biofilter. Makin pendek waktu tinggal maka efisiensi penghilangan semakin rendah. Untuk mendapatkan kualitas air olahan agar memenuhi standar kualitas air baku air minum maka waktu tinggal di dalam reaktor biofilter minimal 1 jam.

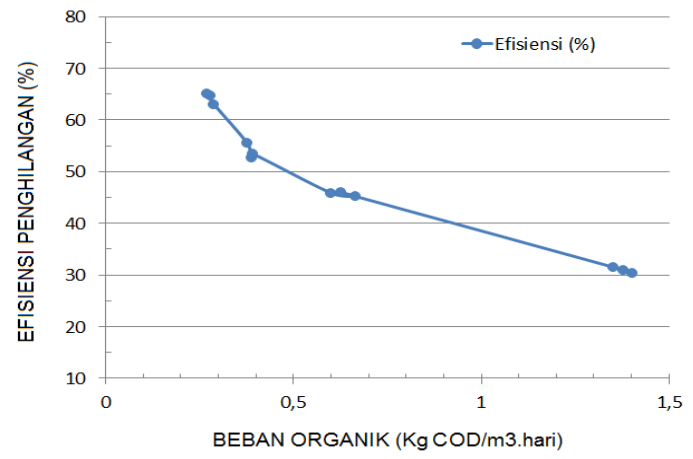

Gambar 18. Hubungan Antara Beban Organik dan Efisiensi Penghilangan Zat Organik Yakni Semakin Besar Beban Organik di Dalam Reaktor Biofilter

Tingginya konsentrasi TSS dan turbidity yang sebagian besar adalah lumpur tanah yang terbawa air hujan menyebabkan lapisan biomassa pada media sarang tawon tertutup. Hal ini menyebabkan effisiensi pengolahan menurun. Kemampuan degradasi polutan akan berkurang dengan adanya lumpur tanah yang mengendap di dalam media biofilter. Untuk itu dalam aplikasinya untuk skala penuh perlu dilengkapi dengan pre-sedimentasi untuk mengendapkan lumpur tanah yang dapat mengganggu proses biodegradasi senyawa polutan di dalam reaktor biofilter.

Berdasarkan beberapa hasil penelitian tersebut di atas dibuat perencanaan reaktor biofilter untuk meningkatkan kualitas air baku yang diambil dari Kali Surabaya.

Beberapa kriteria perencanaan yang akan digunakan untuk merancang reaktor biofilter adalah sebagai berikut:

- Waktu kontak di dalam reaktor biofilter: 0,5-2 jam.

- Beban organik yang digunakan dasar perencanaan: $\quad 0,3-1,0 \mathrm{Kg}$ Organik $/ \mathrm{m}^{3}$ media.hari.

- Perlu mekanisme pengurasan lumpur.

- Perlu penghilangan lumpur (TSS) di dalam air baku sebelum masuk reaktor biofilter.

Reaktor biofilter dirancang agar dapat diintegrasikan dengan unit IPA konvensional (pengendapan kimia) sebagai pengolahan pendahuluan (pre-treatment). Air baku dipompa dari Kanal Intake PDAM dan dialirkan ke bak pengendap tipe Lamella yang dilengkapi dengan 
peralatan pembubuhan bahan kimia koagulan dan soda ash untuk kontrol $\mathrm{pH}$. Pembubuhan bahan kimia koagulan dilakukan apabila konsentrasi TSS air baku tinggi terutama pada saat musim hujan, dan pembubuhan soda ash dilakukan jika $\mathrm{pH}$ air baku rendah. Dari bak pengendap air dialirkan ke reaktor biofilter sambil diaerasi atau dihembus dengan udara. Air limpasan dari reaktor biofilter ditampung di bak penampung antara, selanjutnya akan digunakan sebagai air baku untuk Unit IPA konvensional. Reaktor biofilter harus dilengkapi mekanisme penghilangan lumpur.

\section{KESIMPULAN}

Berdasarkan hasil pembahasan analisa kualitas air Kali Surabaya dan upaya penghilangan polutan organik air Kali Surabaya untuk Air Baku PDAM Surabaya dengan aplikasi teknologi Biofilter dapat disimpulkan bahwa:

- Konsentrasi zat organik di Kali Surabaya relatif tinggi, dan cenderung meningkat terutama pada saat musim kemarau. Hal ini dapat dilihat bahwa konsentrasi BOD tertinggi dapat mencapai $14,84 \mathrm{mg} / \mathrm{l}$ dan konsentrasi COD tertinggi dapat mencapai $53,87 \mathrm{mg} / \mathrm{l}$. Jika dibandingkan dengan Standar Mutu Air Kelas I sesuai dengan PP Nomor 82 Tahun 2001, hal ini menunjukkan bahwa air Kali Surabaya telah tercemar oleh polutan organik cukup tinggi. Disebutkan dalam Standar Mutu Air Kelas I untuk penggunaan air baku air minum konsentrasi BOD maksimum adalah 2 $\mathrm{mg} / \mathrm{l}$, sedangkan untuk mutu air kelas II untuk penggunaan prasarana/sarana rekreasi air, pembudidayaan ikan air tawar, peternakan, air untuk mengairi pertanaman, konsentrasi BOD maksimum $3 \mathrm{mg} / \mathrm{l}$. Untuk konsentrasi COD maksimum adalah $10 \mathrm{mg} / \mathrm{l}$, sedangkan untuk mutu air kelas II untuk penggunaan prasarana/sarana rekreasi air, pembudidayaan ikan air tawar, peternakan, air untuk mengairi pertanaman, konsentrasi BOD maksimum $25 \mathrm{mg} / \mathrm{l}$. Yang perlu diwaspadai adalah pada saat tertentu konsentrasi COD dapat mencapai di atas 50 $\mathrm{mg} / \mathrm{l}$. Hal ini akan menjadi masalah yang serius jika digunakan untuk air baku air minum.

- Dari hasil pemantauan kualitas air Kali Surabaya di lokasi Dam Gunung Sari, senyawa Fenol sering muncul dengan konsentrasi berkisar antara 0 dan $0,039 \mathrm{mg} / \mathrm{l}$, dan bahkan pada bulan Desember konsentrasi Fenol bahkan mencapai $5 \mathrm{mg} / \mathrm{l}$. Berdasarkan Peraturan Pemerintah RI Nomor 82 Tahun 2001, untuk Mutu Air Kelas I untuk penggunaan air baku air minum konsentrasi senyawa Fenol maksimum adalah $1 \mu \mathrm{g} / \mathrm{l}$ atau $0,001 \mathrm{mg} / \mathrm{l}$. Adanya senyawa fenol menunjukkan bahwa Kali Surabaya telah tercemar oleh buangan industri. Dengan adanya senyawa Fenol ini sangat berbahaya jika airnya digunakan sebagai air baku air minum karena senyawa Fenol dapat bereaksi dengan senyawa klor yang digunakan untuk proses disinfeksi, membentuk senyawa klorofenol yang bersifat karsinogen.

- Dengan semakin buruknya kualitas air baku yang berasal dari Kali Surabaya, maka dengan proses pengolahan secara konvensional, maka penggunaan bahan kimia juga semakin besar, akibatnya biaya pengolahan akan menjadi semakin mahal. Selain itu jika konsentrasi senyawa polutan yang ada di dalam air baku sangat tinggi, maka pengolahan secara konvesional dengan pengendapan kimia tidak akan mampu menghilangkan senyawa polutan tersebut. Pembubuhan bahan kimia yang berlebihan terutama klorin akan dapat menyebabkan reaksi samping antara klorin dengan senyawa polutan membentuk senyawa organo-khlorin yang bersifat karsinogen.

- Untuk mengatasi masalah tersebut di atas, salah satu alternatif dapat menggunakan proses pengolahan awal (pretreatment) dengan proses biologis dengan menggunakan teknologi biofilter dengan menggunakan media isian dari bahan plastik tipe sarang tawon (honney comb tube).

\section{PERSANTUNAN}

Penulis menyampaikan terima kasih kepada Perusahaan Umum (PERUM) Jasa Tirta I atas bantuan dan fasilitasinya dalam melakukan kajian penelitian dalam rangka rencana peningkatan kualitas air baku PDAM Surabaya. Terimakasih juga disampaikan kepada Direktur Pusat Teknologi Lingkungan yang telah mendukung terlaksananya kegiatan ini.

\section{DAFTAR PUSTAKA}

1. Anonimous, (2005). Peraturan Pemerintah RI Nomor 16 Tahun 2005 Tentang Pengembangan Sistem Penyediaan Air Minum.

2. Rahmawati, S, Irawan, M.I \& Karnaningroem, N. (2014). Pola Sebaran Polutan di Kali Surabaya Menggunakan Jaringan Kohonen. Prosiding Seminar Teknologi Lingkungan 2014, ITS Surabaya.

3. Anonimous, (1992). World Health Organisation (WHO), Our Planet Our Health: Report of the WHO Commission Health and Environment, World Health Organization, Gevena. 
4. K. Gopal, S.S. Tripathy, J.L. Bersillon, S.P. Dubey. (2007). "Chlorination by products, their toxicodynamics and removal from drinking water". J. Hazard. Mater. Feb. 2007.

5. B. Ramavandi. (2014). "Effect of water quality and operational parameters on trihalomethanes formation potential in Dez River water, Iran". Water Resource, Ind. 6, 36.

6. S. Platikanov, J. Martin, R. Tauler. (2012). Linear and non-linear chemometric modeling of THM formation in Barcelona's water treatment plant. Science of The Total Environment. 432365.

7. Said, N.I. (2008). Teknologi Pengelolaan Air Minum "Teori dan Pengalaman Praktis". PTL-BPPT, Bab 2-54.

8. Said, N.I. (2015). Laporan Kajian Penghilangan Polutan Organik Air Kali Surabaya Untuk Air Baku PDAM Surabaya dengan Teknologi Biofilter. PTL-BPPT.

9. Kominfo, (2017). Tim Patroli Air Temukan Indikasi Pembuangan Limbah di Kali Surabaya. Dinas Komunikasi dan Informatika Provinsi Jawa Timur. Available from:

(http://kominfo.jatimprov.go.id/read/umum/ti m-patroli-air-temukan-indikasi-pembuanganlimbah-di-kali-surabaya)

10. Anonim, (2001). Peraturan Pemerintah RI Nomor 82 Tahun 2001 Tentang Pengelolaan Kualitas Air dan Pengendalian Pencemaran Air.
11. Luvita, V. (2012). Rancang Bangun dan Uji Kinerja Reaktor Hibrida Ozon-Plasma Dingin untuk Pengolahan Limbah Fenolik Cair. Tesis Master Fakultas Teknik Program Magister Teknik Kimia, Depok.

12. Afilah Abd Gami, Mohd Yunus Shukor, Khalilah Abdul Khalil, Farrah Aini Dahalan, Ariff Khalid and Siti Aqlima Ahmad. (2014). "Phenol and its toxicity". Journal of Environmental Microbiology and Toxicology, Vol. 2, No. 1, 11-24.

13. Anonimous, (2012). Sejarah dan Status PDAM Surya Sembada Kota Surabaya. PDAM Surya Sembada Kota Surabaya. Available from:

http://www.pdam-sby.go.id/page.php?get= sejarah_status_pdam

14. Said, N.I. \& Hidayati, S.M., (2000). Penghilangan Polutan Organik di Dalam Air Baku Air Minum dengan Proses Biofilter Tercelup Menggunakan Media Plastik Sarang Tawon. Jurnal Sain \& Teknologi Indonesia, Vol. 2, No. 9. Hal. 44-57. BPPT.

15. Said, N.I. \& Tresnawaty, R. (2001). Penghilangan Amoniak di Dalam Air Baku Air Minnum dengan Proses Biofilter Tercelup menggunakan Media Plastik Sarang Tawon. Jurnal Teknologi Lingkungan, Vol. 2, No. 1. Hal. 11-27. BPPT.

16. Nugroho, R. \& Said, NI. (2011). Perbaikan Kualitas Air Baku Perusahaan Air Minum (PAM) dengan Biofiltrasi. Jurnal Teknolgi Lingkungan, Vol. 12, No. 2, hal. 121-129. BPPT. 